IZA DP No. 6889

Central School Exit Exams and Labor-Market Outcomes

Marc Piopiunik

Guido Schwerdt

Ludger Woessmann

September 2012 


\title{
Central School Exit Exams and Labor-Market Outcomes
}

\author{
Marc Piopiunik \\ Ifo Institute, University of Munich \\ Guido Schwerdt \\ Ifo Institute, University of Munich, \\ CESifo and IZA \\ Ludger Woessmann \\ University of Munich, Ifo Institute, \\ CESifo and IZA
}

\section{Discussion Paper No. 6889 \\ September 2012}

\author{
IZA \\ P.O. Box 7240 \\ 53072 Bonn \\ Germany \\ Phone: +49-228-3894-0 \\ Fax: +49-228-3894-180 \\ E-mail: iza@iza.org
}

\begin{abstract}
Any opinions expressed here are those of the author(s) and not those of IZA. Research published in this series may include views on policy, but the institute itself takes no institutional policy positions. The IZA research network is committed to the IZA Guiding Principles of Research Integrity.

The Institute for the Study of Labor (IZA) in Bonn is a local and virtual international research center and a place of communication between science, politics and business. IZA is an independent nonprofit organization supported by Deutsche Post Foundation. The center is associated with the University of Bonn and offers a stimulating research environment through its international network, workshops and conferences, data service, project support, research visits and doctoral program. IZA engages in (i) original and internationally competitive research in all fields of labor economics, (ii) development of policy concepts, and (iii) dissemination of research results and concepts to the interested public.
\end{abstract}

IZA Discussion Papers often represent preliminary work and are circulated to encourage discussion. Citation of such a paper should account for its provisional character. A revised version may be available directly from the author. 


\section{ABSTRACT}

\section{Central School Exit Exams and Labor-Market Outcomes}

Many countries use centralized exit exams as a governance devise of the school system. While abundant evidence suggests positive effects of central exams on achievement tests, previous research on university-bound students shows no effects on subsequent earnings. We suggest that labor-market effects may be more imminent for students leaving school directly for the labor market and, on rigid labor markets, for unemployment. Exploiting variation in exit-exam systems across German states, we find that central exams are indeed associated with higher earnings for students from school types directly bound for the labor market, as well as with lower unemployment.

JEL Classification: $\quad$ 120, J24, J31, J64

Keywords: central exit exams, earnings, unemployment, Germany

Corresponding author:

Ludger Woessmann

Ifo Institute for Economic Research

at the University of Munich

Poschingerstr. 5

81679 Munich

Germany

E-mail:woessmann@ifo.de

\footnotetext{
* We are grateful to John Bishop, Kerstin Schneider, Ulrich Trautwein, Marty West, and Thomas Zwick, as well as participants at the central exams workshop at the Ifo Institute Munich and at the SOEP@Campus-Workshop at the University of Duisburg-Essen, for comments and discussion. Financial support by the German Federal Ministry of Education and Research for the project "Central Exit Exams as a Governance Instrument in the School System: Labor Market Effects, Transmission Channels, and Effect Heterogeneity" within the BMBF Research Priority "Educational Governance" (SteBis) is gratefully acknowledged.
} 


\section{Introduction}

In a pursuit to raise educational outcomes, education policy in many countries currently aims to improve accountability in the school system. One governance instrument to increase accountability is external exit exams that provide outcome information that is comparable across schools on an external standard. Central school exams have been argued to improve the signaling of educational achievement on the labor market and to increase labor-market productivity through increased human capital. And indeed, external exit exams at the end of secondary school are regularly shown to be associated with better student test scores (e.g., Bishop (2006)). However, critics warn that this result may be related to students' higher testtaking ability, rather than actual higher knowledge and skills, which casts doubt on the genuine improvements in human capital associated with central exams. In fact, it has proven hard to ascertain effects of central exams on labor-market outcomes. In this paper, we show that state-wide external exit exams are significantly related to higher subsequent individual earnings and lower unemployment on the German labor market, in particular for students who leave high school directly for the labor market.

The limited empirical evidence on labor-market effects of central exams in the existing literature is partly due to the lack of within-country variation in examination systems and of datasets that allow linking school examination systems to later labor-market outcomes at the individual level. Thus, Bishop, Moriarty, and Mane (2000) examine the effect of external exit exams across U.S. states, but such an analysis is ultimately limited to a comparison of New York State to all other U.S. states. For Germany, which has more extensive within-country variation across states, Backes-Gellner and Veen (2008) fail to find a positive effect of central school exit exams on labor-market earnings.

We propose two reasons why labor-market effects of central school exit exams might have been missed in the existing research using the valuable German between-state variation. First, in the highly tracked German school system, the existing research focuses on earnings of students of the highest school track that prepares for university entry. But students of the lower school tracks - who are also faced with central exams in some states but not in others may be more likely to see labor-market consequences based on their high-school leaving certificates. They tend to enter the labor market directly after receiving their high-school leaving certificates, whereas the labor-market consequences of school exit exams may be more limited for high-track students who tend to first enter university and only later the labor market, by which time their university diploma may be more important. Second, restricting 
the analysis of labor-market outcomes to earnings may be overly restrictive in the setting of a rigid labor market where earnings structures are mostly determined by central bargaining. When wages cannot adjust, labor-market consequences may emerge in the form of unemployment.

The evidence provided in this paper suggests that both types of reasoning have empirical relevance. Our analysis builds on the fact that until recently, German states were roughly divided in half on whether they have central exams or not. This allows us to observe workers with schooling from systems with central exams and workers with schooling from systems without central exams in the same German labor market. We use two datasets - the German Socio-Economic Panel (SOEP) and the Graduate Panel of the Higher Education Information System (HIS) - that allow us to link the observed state of school degree and exam type of individual students to their later labor-market outcomes in Germany. By doing so, we can also check whether previous results might have been biased towards zero because of attenuation bias from using the state of residence as a proxy for the state in which individuals actually obtained their school degree.

While our results confirm that the existence of central school exit exams is unrelated to the earnings of high-track (Abitur) students, we find that students from the lowest track (Hauptschule) have higher earnings if they received their high-school leaving certificate in a state with central exams. We also find that graduates from both the low-track and the hightrack schools have lower rates of unemployment when their school exit exam was centrally administered. Important associations of central school exams with labor-market outcomes thus surface in areas where research has not looked so far. These associations are consistent with theoretical models (see Section 2.1) that suggest that central exams may have important labor-market consequences when graduates leave school directly for the labor market.

Subsample analyses by gender and age group show that the associations between central exams and labor-market outcomes emerge for both genders but tend to be stronger for females. The earnings associations for low-track graduates are roughly constant across age groups, whereas the unemployment results for low- and high-track graduates tend to decrease with age.

Our results are based on standard cross-sectional earnings functions that express labormarket outcomes as a function of standard factors such as education and age. As such, they have to be viewed as descriptive. Whether the reported associations reflect causal effects depends on the extent to which other, omitted variables relate to both school exam types and labor-market conditions. For example, differences in regional labor markets may coincide 
with high-school examination regimes. Because these regimes have been in place for several decades, it is hard to disentangle whether they are the cause of regional labor-market conditions (including long-term general-equilibrium adjustments of labor markets to regional skill levels) or just correlate with them. ${ }^{1}$ At least, in a set of sensitivity analyses, we confirm that the results are robust to adding controls for a set of factors that may be related to regional labor-market performance independent of the school exam system, such as the share of students in the different school tracks in a state, parental education, and a rich set of more than 60 industry dummies. While our results extend on the current state of the literature on the subject, the observational character of the reported relationships prevents us from going deeper into causal inferences. Thus, we interpret the presented evidence as descriptive patterns that are consistent with theoretical predictions that central school exams can affect labor-market outcomes.

The remainder of the paper is structured as follows. Section 2 provides theoretical background and reviews existing evidence that motivates our analysis. Section 3 briefly describes the examination systems of the different German states and introduces the two longitudinal datasets that allow us to link school exams to labor-market outcomes at the individual level. Section 4 introduces the empirical model and reports our results on the association of central exams with earnings and with unemployment for graduates from different types of high schools. Section 5 concludes.

\section{Conceptual Background and Existing Evidence}

In this paper, we use the term central exams to refer to what Bishop (1997) has termed “curriculum-based external exit examination systems (CBEEES).” He defines CBEEES as 1) producing signals of student achievement that have real consequences for the students; 2) defining achievement relative to an external standard, not relative to other students in the classroom or school; 3) being organized by discipline and keyed to the content of specific course sequences; 4) signaling multiple levels of achievement in the subject, not only a passfail signal; 5) covering almost all secondary school students; and 6) assessing a major portion of what students studying a subject are expected to know.

\footnotetext{
${ }^{1}$ The limited extent and selective nature of cross-state migration, in particular for low-track graduates, prevent us from disentangling school-exam regimes from regional labor markets by looking at between-state movers.
} 


\subsection{Theoretical Background}

The theoretical literature has derived several mechanisms by which central exams may affect the learning outcomes of students and their labor-market performance. The different mechanisms ultimately rest on the observation that central exams provide information that would otherwise not be available.

Models of educational signaling and screening stress that central exams improve the signal of educational achievement for employers and institutions of higher education (e.g., Stiglitz (1975); Becker (1982); Becker and Rosen (1992)). This signal increases the rewards for educational achievement, which in turn creates stronger incentives for students to increase their learning effort. In a similar spirit, principal-agent models of educational standards model how educational credentials affect the level of learning effort that students choose (e.g., Costrell (1994); Betts (1998)).

By providing information on the outcomes of the educational process, central exams can also improve the monitoring of the behavior of teachers and schools. In a principal-agent framework, this reduces inefficiencies in the educational process and raises educational outcomes (Bishop and Woessmann (2004); Bishop (2006)). In addition, central exams may decrease collective peer pressure against learning because they make a collective strategy to lower standards in a classroom futile, which again increases learning outcomes (Bishop and Woessmann (2004); Bishop (2006)).

Human capital theory predicts that such improvements in educational outcomes - i.e., investments in knowledge and skills - in turn increase a person's productivity on the labor market, thereby improving labor-market outcomes (see Becker (1964); Mincer (1974)). ${ }^{2}$

Against this background, we derive two simple extensions of the theoretical predictions of possible labor-market effects of central exit exams that may be relevant in real-world applications. First, the closer entry into the labor market is to the end of high school, the larger will be the signal content of high-school leaving exams. Therefore, labor-market effects of central school exit exams will be highest for students who enter the labor market right after high school. By contrast, they will be lower for high-school graduates who enter college or university before entering the labor market. ${ }^{3}$

\footnotetext{
${ }^{2}$ For the purposes of this paper, we do not aim to distinguish between human capital and pure signaling effects of central exams on the labor market. We simply aim to test whether central exams have implications for individual labor-market outcomes.

${ }^{3}$ Still, Schwerdt and Woessmann (2012) find that grades on high-school leaving certificates have signaling value even for university graduates, in particular in states with central school exit exams.
} 
Second, many real-world labor markets are characterized by institutional structures that limit the extent to which wages can reflect marginal productivity. In situations where wages are compressed due to labor-market rigidities, the labor market may adjust not in terms of prices but in terms of quantities, i.e., unemployment (see, e.g., Nickell, Nunziata, and Ochel (2005) and the references therein for a discussion of the issues involved). Consequently, labor-market effects of central exit exams may become visible in terms of unemployment as much as in terms of earnings when labor markets are rigid.

\subsection{Previous Empirical Evidence}

An extensive empirical literature deals with the effects of external exit exams on students' scores on tests of educational achievement. Evidence from several international student achievement tests shows that students perform substantially better in countries with external exit exams than in countries without them (see Hanushek and Woessmann (2011) for an overview). This has been found on the 1991 International Assessment of Educational Progress (IAEP) math, science, and geography tests (Bishop (1997)), the 1991 International Association for the Evaluation of Educational Achievement (IEA) Reading Literacy study (Bishop (1999)), the 1995 Third International Mathematics and Science Study (TIMSS; cf. Bishop (1997); Woessmann (2003)), the 1999 TIMSS-Repeat study (Woessmann (2005)), the PISA 2000 reading, math, and science tests (Bishop (2006); Fuchs and Woessmann (2007)), and the PISA 2003 reading, math, and science tests (Woessmann, Luedemann, Schuetz, and West (2009)). ${ }^{4}$ The existing cross-country evidence suggests that the effect of external exit exams on student achievement may well exceed a whole grade-level equivalent.

Cross-regional studies in countries with regional variation in examination systems find similar results. Positive effects of external exit exams on test-score outcomes have been shown for Canadian provinces (Bishop (1997, 1999)), for U.S. states (e.g., Graham and Husted (1993); Bishop, Moriarty, and Mane (2000)), and for German states (Jürges, Richter, and Schneider (2005); Jürges, Schneider, and Büchel (2005); Jürges and Schneider (2010); Jürges et al. (2012); Luedemann (2011)). Intriguingly, the estimated size of the cross-regional association of external exit exams with test scores across German states does not differ significantly from the cross-country association across OECD countries (Woessmann (2010)).

\footnotetext{
${ }^{4}$ In panel estimates with country fixed effects using the PISA waves 2000-2009, Hanushek, Link, and Woessmann (2012) find that central exit exams interact positively with the introduction of school autonomy in affecting student outcomes.
} 
Better academic skills as measured by achievement tests have in turn been regularly found to be significantly related to earnings on the labor market (e.g., Mulligan (1999); Murnane, Willett, Duhaldeborde, and Tyler (2000); Lazear (2003); Chetty et al. (2011); see Hanushek and Woessmann (2008, 2011) and Hanushek and Rivkin (2012) for reviews). Combined with the rich evidence on positive effects of central exams on test scores, this provides indirect evidence that central exams might have the potential to positively affect labor-market earnings by raising educational achievement. ${ }^{5}$

However, external testing in the school system can also have negative effects (see Figlio and Loeb (2011) for a review). Critics often argue that test-based accountability systems may only raise test-taking skills but not genuine educational achievement (see Koretz (2002) for a review). In some instances, increased test scores may also just be due to fraudulent behavior like outright cheating, as educators have an incentive to improve observed test outcomes (Jacob and Levitt (2003)). In addition, Jürges and Schneider (2010) find that central exit exams, while improving students' academic skills, negatively affect their attitudes toward learning as indicated in self-reported enjoyment of mathematics, and Jürges et al. (2012) indicate that the positive effect of central exams on curriculum-based knowledge does not extend to a positive effect on mathematical literacy. These results indicate that it is not selfevident that better test scores induced by central exams will translate into better labor-market outcomes.

Therefore, the most straightforward way to test the theoretical predictions on labormarket outcomes is to estimate the effects of central exit exams on the labor market directly. However, the possibility of such analysis is limited by the limited variation in the type of examination systems in most countries and by the lack of datasets that link the type of highschool exit exam to individual labor-market performance. Thus, an analysis of effects of external exit exams in the U.S. ultimately boils down to a comparison of New York State to the remaining states (Bishop, Moriarty, and Mane (2000)). Wider variation across U.S. states is restricted to course graduation requirements and minimum competency exams, which assess only low-level skills in public schools and do not have consequences for university entrance. Based on a longitudinal dataset that allows linking the exam type of individual students with later labor-market outcomes, Bishop and Mane (2001) find minimum

\footnotetext{
${ }^{5}$ In instrumental-variable models of cross-country growth regressions, Hanushek and Woessmann (2012) find that variation in test achievement that stems from whether central exams are in place in a school system or not is significantly positively related to long-run economic growth across countries.
} 
competency exams, but not mere course graduation requirements, to be positively associated with earnings.

The federally structured school systems in Germany provide a much richer testing ground for central-exam effects, as German states are roughly divided in half about whether they have external exit exams or not. To our knowledge, Backes-Gellner and Veen (2008) is the only existing study of effects of central exit exams on the German labor market. Their analysis focuses on earnings equations for holders of the Abitur degree - i.e., graduates of the highest German school track that prepares for university entrance - and does not find a significant association of central exit exams with labor-market earnings.

While the study by Backes-Gellner and Veen (2008) constitutes the best evidence available to date, the previous theoretical considerations suggest that their study design may mean that relevant labor-market effects of central exit exams are missed. In particular, their sample does not include graduates of those German high-school tracks that generally aim for direct entrance into the labor market. In addition, wage rigidities on the German labor market may mean that labor-market effects may surface more in terms of unemployment than in terms of earnings. This motivates and directs our study in this paper. We aim to extend the analysis to take into account graduates who enter the labor market right from high school and to consider unemployment in addition to earnings as a relevant outcome on the German labor market.

\section{The German Education System and Datasets}

\subsection{Exit Examinations in the German School System}

In Germany, children enter primary school (Grundschule) at about age 6. After attending primary school for four years, students are tracked into different secondary school tracks. Based on their academic achievement in primary school and/or parents' wishes, students are allocated to one of several different secondary school types. The three traditional school types - relevant for those who are already in the labor market today - are Hauptschule, Realschule, and Gymnasium. ${ }^{6}$ The lowest track, Hauptschule, provides basic general education and usually lasts five years. Afterwards, graduates usually aim for an apprenticeship on the labor market. The middle track, Realschule, provides a more extensive general education and

\footnotetext{
${ }^{6}$ In some states, a fourth type of secondary schools exists. Comprehensive schools (Gesamtschule) offer all lower and upper secondary education levels. Where comprehensive schools exist, only a minor fraction of students attends this school type.
} 
usually covers grades 5 to 10. While most Realschule graduates also aim for an apprenticeship, the Realschule leaving certificate also qualifies a student to attend certain continuing schools that ultimately lead to a (restricted) entrance qualification for higher education. The highest school track, Gymnasium, provides the most academic education and covers grades 5 to 13. The school leaving certificate from Gymnasium, obtained after 12 or 13 grades and called Abitur, is a prerequisite for attending university or other institutions of higher education. Thus, the Abitur is the only school degree that provides direct entry into tertiary education.

In Germany, responsibility for the education system lies with the federal states. As a result, the institutional setup of the German secondary education system varies across states. In particular, school exit exams that take place at the end of secondary school are differently organized. While school exit exams are externally and centrally administered by the education authority in some states, other states place the responsibility for the exit examinations entirely in the hands of the schools.

Table 1 provides an overview of the type of school exit exams at the end of secondary education by state and school type. ${ }^{7}$ For the most academic school track, Gymnasium, seven of the sixteen federal states employ central exit exams for any subject chosen in the final examinations (Abitur). Several states also use central exit exams for key subjects in the two lower tracks of secondary education, Hauptschule and Realschule. ${ }^{8}$ Note that to some extent, the central exam states differ in the way they construct the exams (either the Ministry of Education or by a specific committee), how the exams are graded (by students' own teachers or by external teachers), and in some other details. ${ }^{9}$

\subsection{Longitudinal Datasets Linking School Exam Type to Labor-Market Outcomes}

To investigate labor-market effects of school exam types, individual labor-market outcomes have to be linked with information on the state in which each individual obtained

\footnotetext{
${ }^{7}$ Since the mid-2000s, most of the states that did not have central exit exams have introduced them. It is too soon to estimate labor-market effects of these reforms. Thus, Table 1 describes the state before these reforms, which is relevant for our sample of individuals who are already in the labor market today.

8 In Bavaria, central exams for Hauptschule students obtaining a "qualified" degree were introduced in 1969. While students obtaining a regular degree from Hauptschule do not take central exams, the fraction of students with a qualified degree was about two thirds in each school year after 1982/83 (no figures available for earlier years). Because all Bavarian Hauptschule students who finished school since 1969 faced the same curriculum, the same teachers, and the same learning incentives, they are all classified as coming from a state with central exams.

${ }^{9}$ See Klemm (1998), Table VIII/2, and Aktionsrat Bildung (2011), Section 2.2, for overviews of how the procedures of the central exit exams for Gymnasium vary across states.
} 
his or her high-school leaving certificate. There are two German datasets that provide such a longitudinal link, the German Socio-Economic Panel (SOEP) and the Graduate Panel of the Higher Education Information System (HIS).

\subsubsection{The German Socio-Economic Panel (SOEP)}

The German Socio-Economic Panel (SOEP) is an annual household panel survey that is representative of the resident population of Germany (for details, see Wagner, Burkhauser, and Behringer (1993) and Schupp and Wagner (2002)). The first wave was conducted in 1984 in West Germany; East Germany was included after reunification in 1990. The SOEP surveys the head of each sampled household and all other individuals over age 17. It contains information on the educational background of the respondents and their parents, employment spells, earnings, and numerous personal characteristics. ${ }^{10}$

Since the crucial information for our analysis is whether an individual's school degree was obtained in a state with or without central exit exams, our samples contain only individuals with information on the federal state in which they obtained their secondary school degree. Because the SOEP survey started collecting this information only in $2001{ }^{11}$ our sample includes only first-time respondents aged 18 and older who entered the SOEP in 2001 or later. Combining the type of the school degree and federal state in which it was acquired, we can identify whether an individual obtained his or her secondary school degree in a state with or without central exit exams. ${ }^{12}$ Note that our way of identifying the state in which the secondary school degree was obtained - and, consequently, our sample restrictions - differ from Backes-Gellner and Veen (2008), who did not use the direct information on the state of secondary school degree but assumed that a person's current state of residence (available for all SOEP respondents) is the same as the state in which he or she finished high school. For our sample, we can identify that 29 percent of Abitur holders (analyzed in their study) live in a state different from their state of last school attendance. ${ }^{13} \mathrm{We}$ aim to avoid this

${ }^{10}$ For questionnaires in German and English, see www.diw.de/soep.

${ }^{11}$ Specifically, SOEP respondents are asked about the "state of last school attendance."

${ }^{12}$ Because individuals with a technical school degree (Fachhochschulreife) often acquire this degree on a (vocational) school after attending Realschule, and because this group comprises only about 7 percent of the sample, we code them together with individuals who obtained a school degree from Realschule (mittlere Reife). Coding individuals with a technical school degree instead together with Abitur holders or excluding them from the sample yields qualitatively very similar results.

${ }^{13}$ Cross-state mobility of lower-track graduates is substantially lower (at 7 percent for Hauptschulabschluss holders and 13 percent for mittlere Reife holders), so that 15 percent of our total sample currently live in a different state from the one in which they obtained their school degree. 
source of measurement error by focusing on those respondents for whom we can observe the state of last school attendance directly.

To determine the association between central exams and labor-market outcomes, we restrict our sample to individuals aged 18 to 65 . We further applied the following sample restrictions: Individuals from East Germany who finished secondary school before 1991, in the GDR, are excluded. Furthermore, individuals from Berlin had to be excluded because in most cases it was not clear whether the school degree was obtained in West or East Berlin (in the former GDR). We also had to exclude Abitur holders from Rhineland-Palatinate (no central exams) and Saarland (central exams) because these two states are coded together in the SOEP data files. Finally, individuals of subsample G (High Income Households) are excluded because this subsample is highly non-representative for the resident population. ${ }^{14}$

The first four columns of Table 2 present descriptive statistics of the SOEP employment and earnings samples. The employment sample contains more than 5,700 individuals with information on the current employment status at the time of the interview for the years 2001 through 2010. Note, however, that the pooled sample is unbalanced since only some individuals are observed throughout the entire period (about 30 percent), while others entered the SOEP survey after 2001 or left the survey before 2010. The employment sample includes all individuals who are either full-time employed or have a regular part-time employment or are registered unemployed. Columns (3) and (4) show that individuals who graduated in states with central exit exams are more likely to be employed at all (either full-time or part-time), to be full-time employed, and less likely to be unemployed. ${ }^{15}$

The earnings sample contains only individuals who are either full-time or part-time employed at the time of the SOEP interviews. The earnings sample consists of more than 5,400 individuals and more than 27,000 observations for the survey waves 2001 through 2010. Earnings are measured as the current gross monthly labor income (in Euro) which is reported for the month of the interview in each wave. Columns (1) and (2) show that gross monthly labor income is on average slightly higher for the group of individuals who graduated from secondary school with central exams.

\footnotetext{
${ }^{14}$ In addition, in the most recent waves the very youngest cohorts are excluded from the sample since some states introduced central exit exams after the school year 2000/01. To maintain only individuals from states with longer-run exit exam traditions, we exclude the few individuals who are below age 25 in the year 2010, below age 24 in 2009, and so on.

15 The difference in average age of more than three years between individuals graduating with and without central exams stems from the fact that all East Germans who graduated before 1991 are excluded from the sample, thus making the East German sample substantially younger, and that a majority of East German states has central exit exams; in addition, Bavaria introduced central exams in Hauptschule only in 1969.
} 


\subsubsection{The Graduate Panel of the Higher Education Information System (HIS)}

The graduate panel of the Higher Education Information System (HIS) is a unique dataset of German university graduates that contains information both on where a graduate went to high school and on his or her labor-market outcomes. Since 1989, selected cohorts of university graduates have been included in large representative surveys conducted by the HIS Ltd.

In this study, we use data for the cohort of individuals graduating from university in 1997. University graduates were surveyed in a first wave about one year after graduation (1998) and again in a second wave about five years after graduation (2003). ${ }^{16}$ The universe of individuals graduating from German universities in the academic year 1997 (September 1996 - September 1997) encompasses 191,948 individuals. Out of this universe, 9,583 graduates were initially sampled in 1998 and 6,220 individuals were sampled again in 2003. Our dataset contains information on the 6,216 graduates who were sampled in both waves. ${ }^{17}$ This corresponds roughly to 3.6 percent of all graduates in 1997 . We restrict the sample further by excluding graduates who obtained their university access authorization outside Germany. Moreover, we exclude individuals who completed their secondary education in the GDR.

Columns (5) and (6) of Table 2 provide descriptive statistics for the HIS sample. All values refer to the year 2003. The table reveals some mean differences between graduates in the HIS data from central and local exam states. In particular, the unconditional statistics suggest that graduates with central exams earn more and are less likely to be unemployed. However, all mean differences are small and statistically insignificant.

\section{Empirical Analysis}

This section presents evidence on the associations between the school exam regime on the one hand and earnings and unemployment on the other hand. We first present the empirical model and then report regression results for earnings and unemployment, respectively.

\footnotetext{
${ }^{16}$ The data were provided by the Gesis-ZA Zentralarchiv für Empirische Wirtschaftsforschung and became available as a scientific use file (ZA 4272) in 2007.

${ }^{17}$ Four observations had to be dropped due to anonymity concerns.
} 


\subsection{Empirical Model}

The main goal of this paper is to investigate the relationship between central school exit exams and labor-market outcomes, namely earnings and unemployment. The analysis makes use of the fact that German states are roughly divided in half on whether they have central exams or not, which allows us to construct a dummy variable indicating whether an individual's school exit degree was obtained in a central exam state or not for each individual in our two datasets. We incorporate this indicator for central exams in standard cross-sectional earnings and unemployment equations that express labor-market outcomes as a function of standard factors such as education and age. Specifically, we employ the following regression specification:

$$
y_{i}=\alpha+\beta_{1} \text { CentralExam }_{i}+\gamma^{\prime} \text { Degree }_{i}+\delta_{1} \text { Age }_{i}+\delta_{2} \text { Age }_{i}^{2}+\lambda^{\prime} X_{i}+\varepsilon_{i},
$$

where the dependent variable, $y_{i}$, is either the natural logarithm of gross monthly labor earnings of individual $i$ or a dummy variable indicating whether individual $i$ is registered as

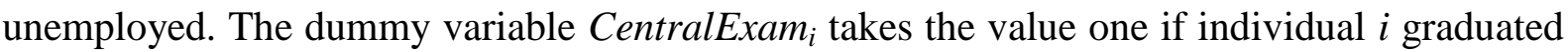
from secondary school in a federal state with central school exit exams, and zero otherwise. The vector Degree $_{i}$ contains two indicator variables for the type of secondary school degree. ${ }^{18}$ Equation (1) also includes age and its square as controls for differences in potential experience. The vector $X_{i}$ contains additional individual information such as gender, parental education, and migration background, as well as an indicator for living in East Germany. ${ }^{19}$ Additionally, year dummies are included to control for macroeconomic developments. ${ }^{20} \varepsilon_{i}$ is an error term. ${ }^{21}$

Our key parameter of interest is $\beta_{1}$. In the case of the modified Mincerian earnings function, it measures the earnings differential between graduates from states with central school exit exams and graduates from states with local exams. Previous evidence suggests that this difference is not statistically different from zero for graduates of the highest German school track (Backes-Gellner and Veen (2008)). Our estimation might, however, reveal a

\footnotetext{
18 The lowest school track Hauptschule is the omitted category.

${ }^{19}$ The indicator for individuals living in East Germany captures historically determined differences in East German labor markets that are independent of school exam systems; results are qualitatively the same without an East Germany indicator.

${ }^{20}$ Approximately 15 percent of the earnings observations are imputed by the SOEP team. We include a dummy variable with the imputation status in all SOEP regressions.

${ }^{21}$ As the SOEP earnings sample is pooled over several years, the error term is clustered at the individual level. The estimation of equation (1) based on the HIS dataset is performed without clustering. An analysis with clustering at the level of the state of graduation does not change results qualitatively.
} 
different result, because our approach extends this earlier empirical analysis in two important ways: First, we use a direct and more reliable measure of the state in which the secondary school degree was obtained, thereby reducing measurement error in the central exams indicator. Second, we extend the analysis to graduates from the other tracks of the secondary school system. Thus, our estimate of $\beta_{1}$ measures the average association between central school exit exams and earnings for all secondary school graduates.

Moreover, one potential reason why previous empirical work has failed to document significant labor-market effects of central exit exams might be that such effects materialize in terms of differences in labor demand rather than earnings differentials. This concern might be especially relevant in labor markets with substantial wage rigidities like Germany. Therefore, we estimate equation (1) also with an unemployment indicator as dependent variable. In this case, $\beta_{1}$ measures the average difference in unemployment probabilities between graduates from states with central school exit exams and graduates from states with local school exit exams.

As argued above, central exams might generate different labor-market effects when graduates enter the labor market immediately after graduation from secondary school compared to situations where secondary schooling is succeeded by further educational spells. If so, the estimate of $\beta_{1}$ might hide significant effects of central exams for subgroups of the population.

Guided by these theoretical considerations, we extend equation (1) to allow for heterogeneous effects of central exams depending on the type of secondary school degree:

$$
y_{i}=\alpha+\beta_{2}^{\prime}\left(\text { CentralExam }_{i} \times \text { Degree }_{i}\right)+\gamma^{\prime} \text { Degree }_{i}+\delta_{1} \text { Age }_{i}+\delta_{2} \text { Age }_{i}^{2}+\lambda^{\prime} X_{i}+\varepsilon_{i}
$$

where the central-exam indicator CentralExam $i$ is interacted with a vector of dummy variables indicating graduation from one of the three secondary school tracks, Degree $_{i}$. The three key parameters of interest are included in the coefficient vector $\beta_{2}$. They identify earnings differences and differences in unemployment probabilities between graduates from states with central exit exams and graduates from states with local exams by type of secondary education.

We estimate all specifications by OLS, where the identifying variation is in the crosssection. $^{22}$ Thus, our results have to be viewed as descriptive. Whether the estimated

\footnotetext{
${ }^{22}$ In the SOEP estimations, each observation is weighted by the individual's cross-sectional weight of the respective observation year, thus taking into account the differential sampling probabilities of the individuals. In addition, these weights have been normalized such that each of the observation years, 2001-2010, receives the same weight.
} 
coefficients reflect causal effects depends on the extent to which other, omitted variables relate to both school exam systems and labor-market conditions. Regional differences that coincide with high-school examination regimes might be potential confounding factors. We partly address this issue by conducting additional robustness checks, in particular controlling for state-level shares of students in the different school tracks and extensive industry indicators. However, as examination regimes have been in place for several decades, it is hard to disentangle whether they are the cause of regional differences (e.g., regional labor-market conditions) or just correlate with them. In fact, it is a positive aspect of the empirical strategy that it captures any general-equilibrium effects of central exam systems, such as responses of employers and work organizations to changed levels of knowledge and skills of the employees. Note that it is impossible to condition on state-level averages of earnings and unemployment, as these effectively provide the identifying variation in the empirical model. ${ }^{23}$ As a consequence, the descriptive estimates from the empirical model can only be interpreted as being consistent (or not) with specific theoretical models, whereas causality has not been established.

\subsection{Central Exams and Earnings}

\subsubsection{Main Results}

We start by analyzing the association between central exams and earnings. The first column of Table 3 reports coefficient estimates of equation (1) for earnings based on the SOEP dataset. The estimates reveal several typical features of estimated Mincerian earnings functions with school degrees as proxy for human capital investments in Germany that are in line with previous evidence. We find significant returns to higher school degrees of a magnitude comparable to the returns reported in Dustmann (2004). The results also confirm the existence of a large gender wage gap in Germany (Fitzenberger and Wunderlich (2002)), as well as the standard hump-shaped relationship between earnings and age.

\footnotetext{
${ }^{23}$ We refrain from identification from individuals who moved from one state to another between graduation and working for two main reasons. First, cross-state mobility is very limited in Germany, rendering samples that are too small for identification. For example, only 7 percent of graduates from the lowest-track school live in a different state than the one in which they graduated (not even considering that any many of them live in a state with the same type of examination regime). Second, it seems anything but random who chooses to migrate between states, and the patterns of selectivity are likely to differ both between the direction of migration (from central-exam to non-central-exam states or the reverse) and between graduates from different school tracks. Thus, the existing migration has to be viewed as so selective that estimates would seems likely to be much more biased than cross-sectional analyses. Consequently, our analysis does not include state-of-residence fixed effects.
} 
Most importantly, the estimated coefficient on the central-exam dummy shows that graduates from central exam states have on average 6.4 percent higher earnings compared to graduates from states with local exams. However, as the next specification shows, this average estimate hides important heterogeneity by type of secondary schooling.

Column (2) reports coefficient estimates of equation (2) based on the SOEP sample. Among the three school-track types, only the estimated coefficient on the interaction term of central exams with the lowest track, Hauptschule, is statistically significantly different from zero with an effect size of 11.5 percent higher earnings. The estimates of the interaction terms of central exams with the two higher tracks of secondary education, Realschule and Abitur, are also positive, but substantially smaller and statistically insignificant.

The latter result is also confirmed with our second dataset, the HIS university graduate survey. As shown in column (3), the point estimate of the central-exam dummy for university graduates is very small and statistically insignificant, in line with the SOEP results for hightrack students. ${ }^{24}$ This finding shows that the result in Backes-Gellner and Veen (2008) was not just driven by measurement error in their method to determine the state in which an individual obtained his or her secondary school degree (see Section 3.2.1 above), but rather reflects a genuine lack of significant association for high-track graduates.

These results suggest two main conclusions: First, they confirm previous findings that the existence of central school exit exams is not significantly related to the earnings of high-track (Abitur) students. Moreover, there is also no significant relationship between central exit exams and earnings for middle-track (Realschule) and successful university graduates. Second, however, students from the lowest track (Hauptschule) have significantly higher earnings if they received their high-school leaving certificate in a state with central exams rather than otherwise. These findings are in line with the hypothesis that central exams are most likely to affect labor-market outcomes when graduates enter the labor market immediately after graduating from secondary school. ${ }^{25}$

\subsubsection{Robustness Tests}

In what follows, we conduct several sensitivity analyses to check the robustness of this associational evidence. We start by evaluating whether the positive association between

\footnotetext{
${ }^{24}$ The negative coefficient estimate on age in this sample of individuals who all graduated from university in the same year likely reflects the fact that those who took longer to graduate are negatively selected.

${ }^{25}$ The pattern of effects for low-track students but not for high-track students is also consistent with the pattern of test-score results in Jürges et al. (2012).
} 
central exams and earnings for students from the lowest high-school track prevails in different age cohorts and genders. To do so, we split the sample in six subsamples by age and gender. The results shown in Table 4 reveal that the positive central exam-earnings relationship among low-track graduates is roughly constant over the three age groups 18-29 years, 30-49 years, and 50-65 years (although statistically significant only for the middle category).

A comparison of coefficient magnitudes suggests that the association is stronger for females. As for the entire population, we do not find any statistically significant association between central exit exams and earnings for male students from the other two school tracks. As for males, there is no relationship for female Abitur holders. But for females from the medium track, there is also a statistically significant and substantial positive association between central exams and earnings in the young and the old age groups. ${ }^{26}$

In sum, central exams are significantly positively related to earnings among individuals who graduated from low-track schools (Hauptschule) and for young and older females with a degree from medium-track schools (Realschule). There is no such relationship for the other subgroups.

As additional robustness checks, we estimate alternative specifications of equation (2). Table 5 presents results from estimating these different specifications for the entire sample. Our main specification does not include an indicator for full-time employment as we view it as an endogenous variable. Part of a positive effect of central exams might work through an increased probability to work full-time. However, even when controlling for full-time employment, central exams remain highly significantly positively associated with earnings for individuals from the lowest school track (column (1)). The point estimate drops slightly to $0.082 .{ }^{27}$ Our main findings are also robust in a specification that does not include parents' education levels as control variables, leaving the point estimate unchanged at 0.114 (column (2)).

Another possible concern is that different shares of low-, medium-, and high-track students within a state might lead to different average labor-market success of the respective student groups. For example, a large share of low-track students might imply higher average earnings for individuals from that school track because also more able students attend this

26 The gender difference in the associations between central exams and earnings of medium-track (Realschule) graduates is statistically significant at the 10 percent level.

${ }^{27}$ Note that controlling for the labor supply effect of full-time employment substantially reduces the estimate of the gender wage gap. 
school type in the respective state. Column (3) reveals, however, that our main finding is unaffected by including the shares of low- and medium-track students at the state level.

Finally, the industry structure is an important factor in regional labor-market performance. While the industry structure may be partly endogenous to the educational achievement level that stems from the exam system, it is also conceivable that a state's preexisting industry structure is related to the examination type and has time-consistent components. In the latter case, the reported associations would not capture an effect of central exams. However, as indicated in column (4) of Table 5, our findings are robust to including a rich set of dummies for as many as 61 industries. This finding indicates that our results neither capture spurious associations driven by state's industry structures, nor are they driven by self-selection of individuals with the lowest school degree from states with central exams into industries that pay higher wages.

In sum, the robustness checks indicate that our finding of a positive association between central exams and earnings of low-track students (Hauptschule) does not depend on differences in full-time employment, in parental education, in school-track shares, or on selection into industries.

\subsection{Central Exams and Unemployment}

We next turn to the analysis of whether central exams are associated with a second labormarket outcome, namely unemployment. Table 6 reports coefficient estimates of equation (1) with an unemployment indicator as dependent variable. ${ }^{28}$ Results indicate a significant negative association between central exit exams and the probability of being unemployed (column (1)). Graduates from central exam states are 2.4 percentage points less likely to be registered as unemployed compared to graduates from local exam states.

Again, the average effect conceals heterogeneity between school tracks. Column (2) shows estimation results based on equation (2). Results indicate that the average result is mainly driven by graduates from the lowest track, but also by individuals from the highest track. On average, central exit exams are associated with a 4.3 percentage point lower unemployment probability for graduates from low-track high schools and with a 3.2 percentage point lower unemployment probability for graduates from high-track high

\footnotetext{
${ }^{28}$ Despite the binary nature of the outcome variable, reported coefficients are estimated by OLS. We regard a linear probability model as a good approximation of the conditional expectation function of interest. Probit estimations produce almost identical results for the effect of interest.
} 
schools. ${ }^{29}$ There is no significant association for graduates from the middle track (column (2)).

We interpret these findings as evidence that on rigid labor markets, possible labor-market effects can materialize in terms of unemployment as much as in terms of earnings. While these results confirm the insight from the earnings analysis that labor-market effects of central exams are particularly pronounced for graduates from the lowest track that directly leads into the labor market, they also point to the existence of labor-market effects other than earnings effects for graduates from the highest track.

At the same time, there is no significant association in the HIS dataset of successful university graduates (column (3)). The difference to the significant association in the case of high-track graduates in the SOEP sample may reflect the facts that individuals in the HIS panel have been successful at university and that they are still quite young.

Analogously to the earnings analysis, we conduct several sensitivity analyses to check the robustness of the unemployment results. Table 7 presents gender-age subgroup analyses of the unemployment specification. The results reveal that the unemployment results for both low-track and high-track graduates apply to both males and females in the age ranges of 18-29 and 30-49 years, but not in the age range of 50-65 years.

In analogy to Table 5 for the earnings results, Table 8 reports robustness checks for the unemployment results. Column (1) presents estimation results without controls for parental education and column (2) includes the shares of low- and medium-track students at the state level as additional control variables. The point estimates change only slightly and thus confirm our previous findings of a significant negative relationship between central school exams and the probability of being unemployed among low-track and high-track graduates.

\section{Conclusions}

This paper provides new evidence on the relationship between central school exit exams and labor-market outcomes. It confirms previous findings that central exit exams are not significantly related to earnings for graduates of secondary-school tracks that typically lead to higher education in Germany. However, we present new evidence of positive associations of central exit exams with earnings for graduates of the lowest track of secondary education. In addition, central exit exams are negatively associated with unemployment for graduates from

\footnotetext{
${ }^{29}$ Results are qualitatively similar when a binary employment indicator (full-time or part-time employed vs. non-employed) is used as the outcome variable in a sample that also includes individuals who do not work for other reasons (e.g., housewives or women on maternity leave).
} 
both the low-track and the high-track schools. On average, central exit exams are associated with 11.5 percent higher earnings and 4.3 percentage points lower unemployment probability for graduates from low-track high schools, as well as with 3.2 percentage points lower unemployment probability for graduates from high-track high schools. While the effects on earnings for low-track graduates are roughly constant across age groups, the unemployment effects for low- and high-track graduates is present only for workers below age 50 .

We interpret the results as descriptive rather than causal because it is not clear to what extent all confounding factors could be controlled for in the cross-sectional setting. Still, the descriptive findings constitute value-added over what we knew so far and shed new light on the ongoing debate about the benefits of central school exit examinations. In contrast to existing labor-market evidence, they are consistent with theoretical models that predict positive effects of central exams on the labor market.

Furthermore, the findings indicate important heterogeneity in the associations which points towards relevant details of the possible mechanism by which central exams may affect the labor market. In particular, they visualize that the type of education matters in an empirical analysis of the relationship between exam type and labor-market outcomes. While previous analysis for Germany focused on the earnings of graduates from the highest track of secondary education, our results suggest that effects might exist especially for graduates from the lowest track that leads directly into the labor market. If central exit exams affect student achievement and labor-market outcomes mainly through an increased informational content of the final grade, we would expect central-exam effects to be strongest in situations where labor-market entry follows directly after graduation. This is typically the case for graduates from the lowest track of secondary education in Germany, but not for graduates from higher tracks. Hence, this theoretical argument can reconcile the empirical findings. Additionally, the findings suggest that on rigid labor markets, possible labor-market effects can materialize in terms of unemployment as much as in terms of earnings. 


\section{References}

Aktionsrat Bildung. 2011. Gemeinsames Kernabitur: Zur Sicherung von nationalen Bildungsstandards und fairem Hochschulzugang. Münster: Waxmann.

Backes-Gellner, Uschi, and Stephan Veen. 2008. "The consequences of central examinations on educational quality standards and labour market outcomes." Oxford Review of Education 34, no. 5: 569-588.

Becker, Gary S. 1964. Human capital: A theoretical and empirical analysis, with special reference to education. New York, NY: National Bureau of Economic Research.

Becker, William E. 1982. "The educational process and student achievement given uncertainty in measurement." American Economic Review 72, no. 1: 229-236.

Becker, William E., and Sherwin Rosen. 1992. "The learning effect of assessment and evaluation in high school." Economics of Education Review 11, no. 2: 107-118.

Betts, Julian R. 1998. "The impact of educational standards on the level and distribution of earnings." American Economic Review 88, no. 1: 266-275.

Bishop, John H. 1997. "The effect of national standards and curriculum-based examinations on achievement." American Economic Review 87, no. 2: 260-264.

1999. "Are national exit examinations important for educational efficiency?" Swedish Economic Policy Review 6, no. 2: 349-398.

2006. "Drinking from the fountain of knowledge: Student incentive to study and learn - Externalities, information problems, and peer pressure." In Handbook of the Economics of Education, edited by Eric A. Hanushek and Finis Welch. Amsterdam: North Holland: 909-944.

Bishop, John H., and Ferran Mane. 2001. "The impacts of minimum competency exam graduation requirements on high school graduation, college attendance and early labor market success." Labour Economics 8, no. 2: 203-222.

Bishop, John H., Joan Y. Moriarty, and Ferran Mane. 2000. "Diplomas for learning, not seat time: The impact of New York Regents examinations." Economics of Education Review 19, no. 4: 333-349.

Bishop, John H., and Ludger Woessmann. 2004. "Institutional effects in a simple model of educational production." Education Economics 12, no. 1: 17-38.

Chetty, Raj, John N. Friedman, Nathaniel Hilger, Emmanuel Saez, Diane Whitmore Schanzenbach, and Danny Yagan. 2011. "How does your kindergarten classroom affect your earnings? Evidence from Project Star." Quarterly Journal of Economics 126, no. 4: 1593-1660.

Costrell, Robert M. 1994. "A simple model of educational standards." American Economic Review 84, no. 4: 956-971.

Dustmann, Christian. 2004. "Parental background, secondary school track choice, and wages." Oxford Economic Papers 56, no. 2: 209-230.

Figlio, David, and Susanna Loeb. 2011. "School accountability." In Handbook of the Economics of Education, Vol. 3, edited by Eric A. Hanushek, Stephen Machin, and Ludger Woessmann. Amsterdam: North Holland: 383-421. 
Fitzenberger, Bernd, and Gaby Wunderlich. 2002. "Gender wage differences in West Germany: A cohort analysis." German Economic Review 3, no. 4: 379-414.

Fuchs, Thomas, and Ludger Woessmann. 2007. "What accounts for international differences in student performance? A re-examination using PISA data." Empirical Economics 32, no. 2-3: 433-462.

Graham, Amy E., and Thomas A. Husted. 1993. "Understanding state variations in SAT scores." Economics of Education Review 12, no. 3: 197-202.

Hanushek, Eric A., Susanne Link, and Ludger Woessmann. 2012. "Does school autonomy make sense everywhere? Panel estimates from PISA." Journal of Development Economics, forthcoming.

Hanushek, Eric A., and Steven G. Rivkin. 2012. "The distribution of teacher quality and implications for policy." Annual Review of Economics 4, forthcoming.

Hanushek, Eric A., and Ludger Woessmann. 2008. "The role of cognitive skills in economic development." Journal of Economic Literature 46, no. 3: 607-668. . 2011. "The economics of international differences in educational achievement." In Handbook of the Economics of Education, Vol. 3, edited by Eric A. Hanushek, Stephen Machin, and Ludger Woessmann. Amsterdam: North Holland: 89-200.

- 2012. "Do better schools lead to more growth? Cognitive skills, economic outcomes, and causation." Journal of Economic Growth, forthcoming.

Jacob, Brian A., and Steven D. Levitt. 2003. "Rotten apples: An investigation of the prevalence and predictors of teacher cheating." Quarterly Journal of Economics 118, no. 3: 843-877.

Jürges, Hendrik, Wolfram F. Richter, and Kerstin Schneider. 2005. "Teacher quality and incentives: Theoretical and empirical effects of standards on teacher quality." FinanzArchiv 61, no. 3: 298-326.

Jürges, Hendrik, and Kerstin Schneider. 2010. "Central exit examinations increase performance... but take the fun out of mathematics." Journal of Population Economics 23, no. 2: 497-517.

Jürges, Hendrik, Kerstin Schneider, and Felix Büchel. 2005. "The effect of central exit examinations on student achievement: Quasi-experimental evidence from TIMSS Germany." Journal of the European Economic Association 3, no. 5: 1134-1155.

Jürges, Hendrik, Kerstin Schneider, Martin Senkbeil, and Claus H. Carstensen. 2012. "Assessment drives learning: The effect of central exit exams on curricular knowledge and mathematical literacy." Economics of Education Review 31, no. 1: 56-65.

Klemm, Klaus. 1998. "Steuerung der Schulentwicklung durch zentrale Leistungskontrollen?" In Jahrbuch der Schulentwicklung: Daten, Beispiele und Perspektiven, Vol. 10, edited by Hans-Günter Rolff, Karl-Oswald Bauer, Klaus Klemm, and Hermann Pfeiffer. Weinheim: Juventa.

Koretz, Daniel. 2002. "Limitations in the use of achievement tests as measures of educator's productivity." Journal of Human Resources 37, no. 4: 752-777.

Lazear, Edward P. 2003. "Teacher incentives." Swedish Economic Policy Review 10, no. 3: 179-214. 
Luedemann, Elke. 2011. "Intended and unintended short-run effects of the introduction of central exit exams: Evidence from Germany." In Elke Luedemann, Schooling and the formation of cognitive and non-cognitive outcomes, Chapter 4. ifo Beiträge zur Wirtschaftsforschung 39. Munich: ifo Institut.

Mincer, Jacob. 1974. Schooling, experience, and earnings. New York: NBER.

Mulligan, Casey B. 1999. "Galton versus the human capital approach to inheritance." Journal of Political Economy 107, no. 6, pt. 2: S184-S224.

Murnane, Richard J., John B. Willett, Yves Duhaldeborde, and John H. Tyler. 2000. "How important are the cognitive skills of teenagers in predicting subsequent earnings?" Journal of Policy Analysis and Management 19, no. 4: 547-568.

Nickell, Stephen, Luca Nunziata, and Wolfgang Ochel. 2005. "Unemployment in the OECD since the 1960s: What do we know?" Economic Journal 115, no. 500: 1-27.

Schupp, Jürgen, and Gerd G. Wagner. 2002. "Maintenance of and innovation in long-term panel studies: The case of the German Socio-Economic Panel (GSOEP)." Allgemeines Statistisches Archiv 86, no. 2: 163-175.

Schwerdt, Guido, and Ludger Woessmann. 2012. "The information value of central school exams." CESifo Working Paper, forthcoming. Munich: CESifo.

Stiglitz, Joseph E. 1975. "The theory of "screening," education, and the distribution of income." American Economic Review 65, no. 3: 283-300.

Wagner, Gerd G., Richard V. Burkhauser, and Friederike Behringer. 1993. "The English language public use file of the German Socio-Economic Panel." Journal of Human Resources 28, no. 2: 429-433.

Woessmann, Ludger. 2003. "Schooling resources, educational institutions, and student performance: The international evidence." Oxford Bulletin of Economics and Statistics 65, no. 2: 117-170.

- 2005. "The effect heterogeneity of central exams: Evidence from TIMSS, TIMSSRepeat and PISA." Education Economics 13, no. 2: 143-169.

2010. "Institutional determinants of school efficiency and equity: German states as a microcosm for OECD countries." Jahrbücher für Nationalökonomie und Statistik / Journal of Economics and Statistics 230, no. 2: 234-270.

Woessmann, Ludger, Elke Luedemann, Gabriela Schuetz, and Martin R. West. 2009. School accountability, autonomy, and choice around the world. Cheltenham, UK: Edward Elgar. 
Table 1: Central School Exit Exams by State and Secondary School Type

\begin{tabular}{|c|c|c|c|}
\hline & Hauptschule & Realschule & Gymnasium (Abitur) \\
\hline Baden-Württemberg & Yes & Yes & Yes \\
\hline Bavaria & Yes $^{a)}$ & Yes & Yes \\
\hline \multicolumn{4}{|l|}{ Berlin } \\
\hline \multicolumn{4}{|l|}{ Brandenburg } \\
\hline \multicolumn{4}{|l|}{ Bremen } \\
\hline \multicolumn{4}{|l|}{ Hamburg } \\
\hline \multicolumn{4}{|l|}{ Hesse } \\
\hline \multicolumn{4}{|l|}{ Lower Saxony } \\
\hline Mecklenburg-West Pomerania & & Yes & Yes \\
\hline \multicolumn{4}{|l|}{ North Rhine-Westphalia } \\
\hline \multicolumn{4}{|l|}{ Rhineland-Palatinate } \\
\hline Saarland & & & Yes \\
\hline Saxony & Yes & Yes & Yes \\
\hline Saxony-Anhalt & & Yes & Yes \\
\hline \multicolumn{4}{|l|}{ Schleswig-Holstein } \\
\hline Thuringia & Yes & Yes & Yes \\
\hline
\end{tabular}

Notes: Central school exit exams as of 2001. a) Central exit exams introduced in 1969.

Sources: Jürges, Schneider, and Büchel (2005), Klemm (1998), and State Ministries of Education. 


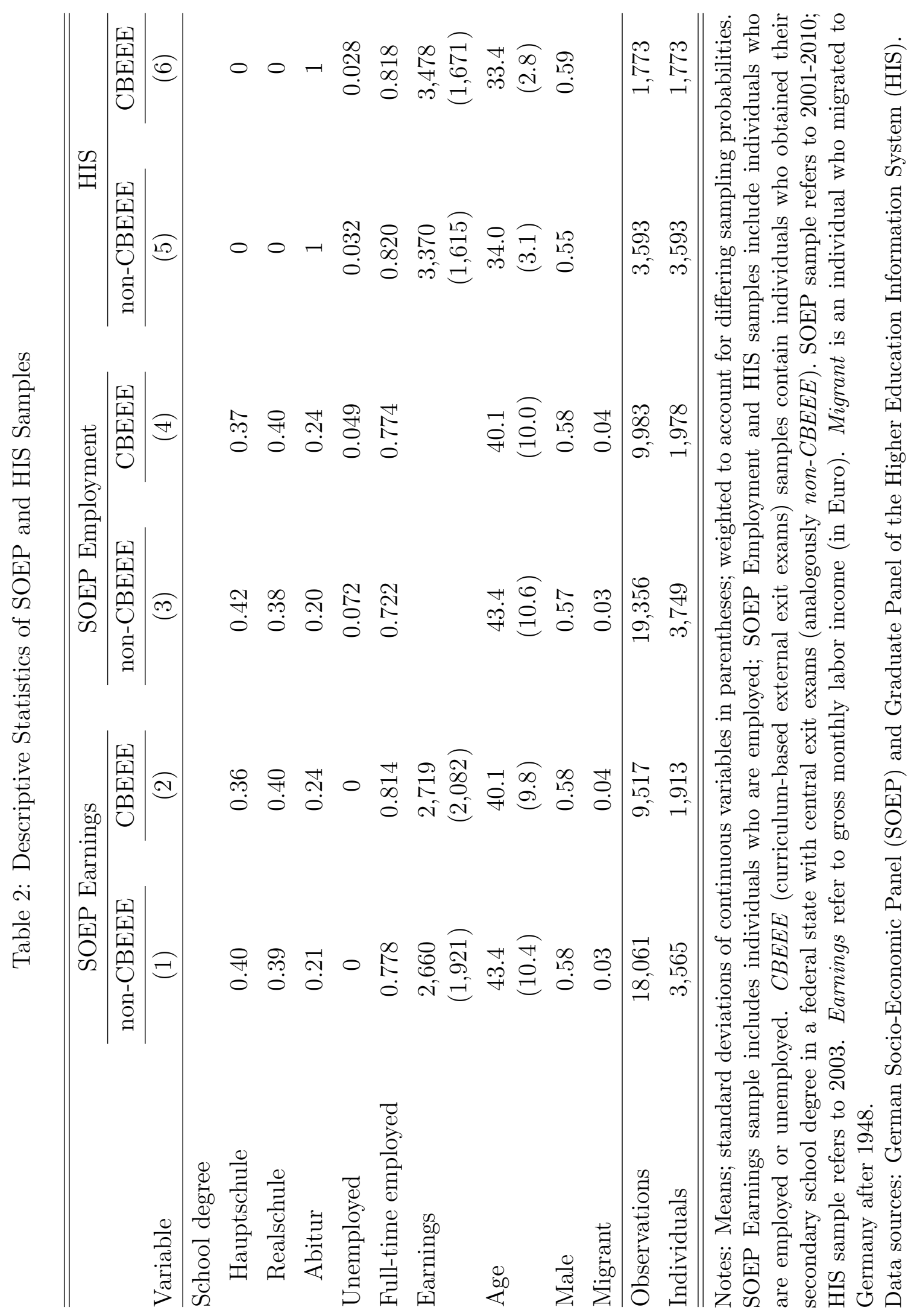


Table 3: Central Exit Exams and Earnings

\begin{tabular}{|c|c|c|c|}
\hline & \multicolumn{2}{|r|}{ SOEP } & \multirow{3}{*}{$\begin{array}{l}\text { HIS } \\
(3) \\
\end{array}$} \\
\hline & Main Effect & Interactions with School Type & \\
\hline & $(1)$ & $(2)$ & \\
\hline \multirow[t]{2}{*}{ CBEEE } & $.064^{* * *}$ & & \\
\hline & $(.019)$ & & \\
\hline \multirow[t]{2}{*}{ Hauptschule*CBEEE } & & $.115^{* * *}$ & \\
\hline & & $(.032)$ & \\
\hline \multirow[t]{2}{*}{ Realschule*CBEEE } & & .036 & \\
\hline & & $(.027)$ & \\
\hline \multirow[t]{2}{*}{ Abitur*CBEEE } & & .031 & .003 \\
\hline & & $(.041)$ & $(.015)$ \\
\hline \multirow[t]{2}{*}{ Realschule } & $.219^{* * *}$ & $.246^{* * *}$ & \\
\hline & $(.021)$ & $(.026)$ & \\
\hline \multirow[t]{2}{*}{ Abitur } & $.463^{* * *}$ & $.493^{* * *}$ & \\
\hline & $(.030)$ & $(.039)$ & \\
\hline \multirow[t]{2}{*}{ Age } & $.048^{* * *}$ & $.047^{* * *}$ & $-.016^{* * *}$ \\
\hline & $(.006)$ & $(.006)$ & $(.002)$ \\
\hline \multirow[t]{2}{*}{ Age squared } & $-.458^{* * *}$ & $-.447^{* * *}$ & \\
\hline & $(.074)$ & $(.075)$ & \\
\hline \multirow[t]{2}{*}{ Male } & $.614^{* * *}$ & $.615^{* * *}$ & $.372^{* * *}$ \\
\hline & $(.019)$ & $(.019)$ & $(.015)$ \\
\hline \multirow[t]{2}{*}{ Migrant } & -.001 & -.004 & \\
\hline & $(.037)$ & $(.037)$ & \\
\hline Year dummies & Yes & Yes & No \\
\hline Indicator for imputed earnings & Yes & Yes & No \\
\hline East Germany & Yes & Yes & Yes \\
\hline Father's education & Yes & Yes & Yes \\
\hline Mother's education & Yes & Yes & Yes \\
\hline Observations & 27,578 & 27,578 & 4516 \\
\hline Individuals & 5,478 & 5,478 & 4516 \\
\hline Adj. $R^{2}$ & .303 & .304 & .149 \\
\hline
\end{tabular}

Notes: Dependent variable: Log of gross monthly labor income. Sample includes individuals who are employed. SOEP sample refers to 2001-2010; HIS sample refers to 2003. Weighted least squares regressions. Robust standard errors clustered at the person level in parentheses. CBEEE (curriculum-based external exit exams) equals 1 if individual graduated in a federal state with central school exit exams ( 0 otherwise). Hauptschule (lowest school track) is the omitted category of secondary school dummies. Parents' education contains dummy variables for school degrees. Coefficient on age squared is multiplied by 1,000 .

Significance levels: ${ }^{*} \mathrm{p}<0.10,{ }^{* *} \mathrm{p}<0.05,{ }^{* * *} \mathrm{p}<0.01$.

Data sources: German Socio-Economic Panel (SOEP) and Graduate Panel of the Higher Education Information System (HIS). 


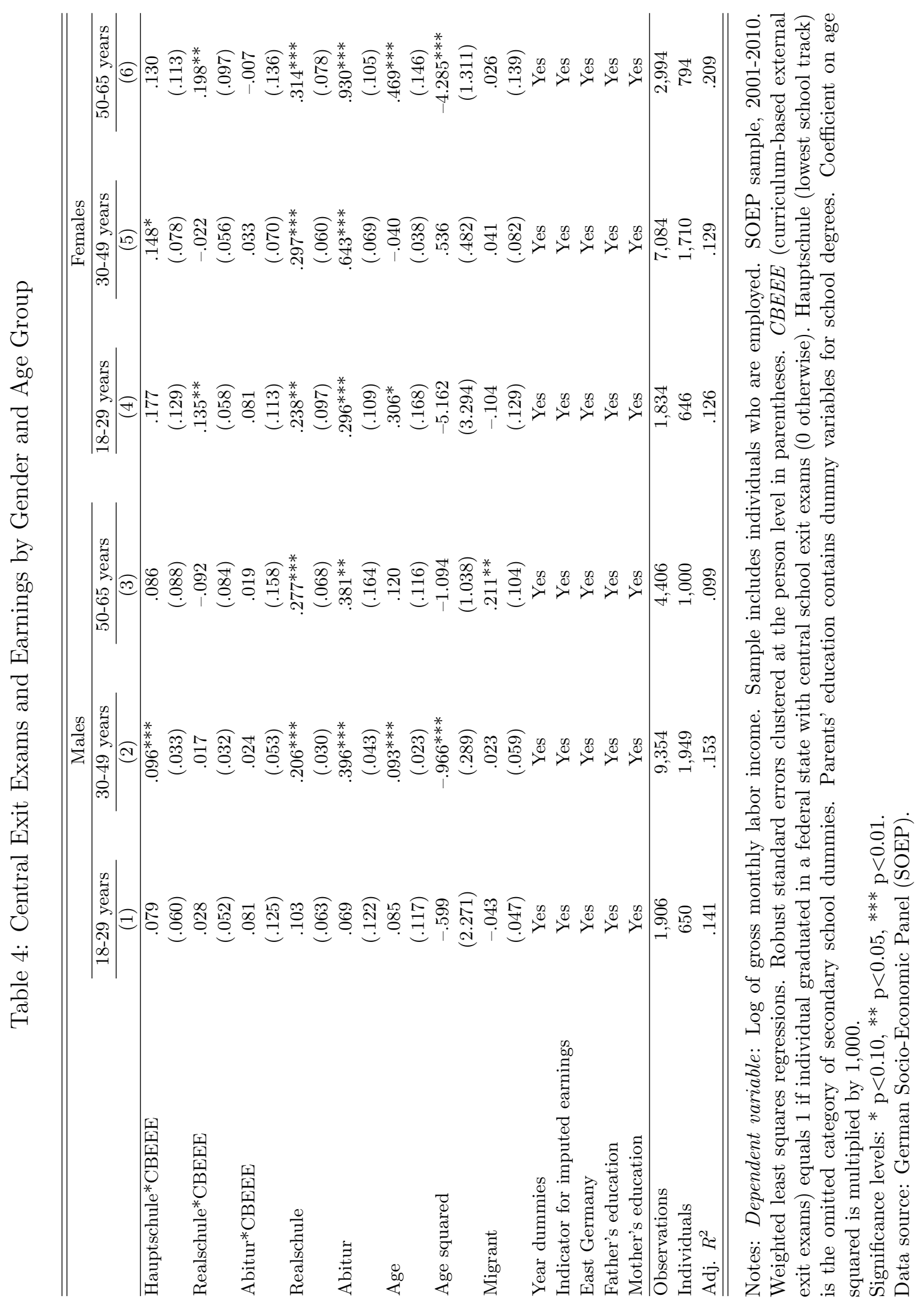




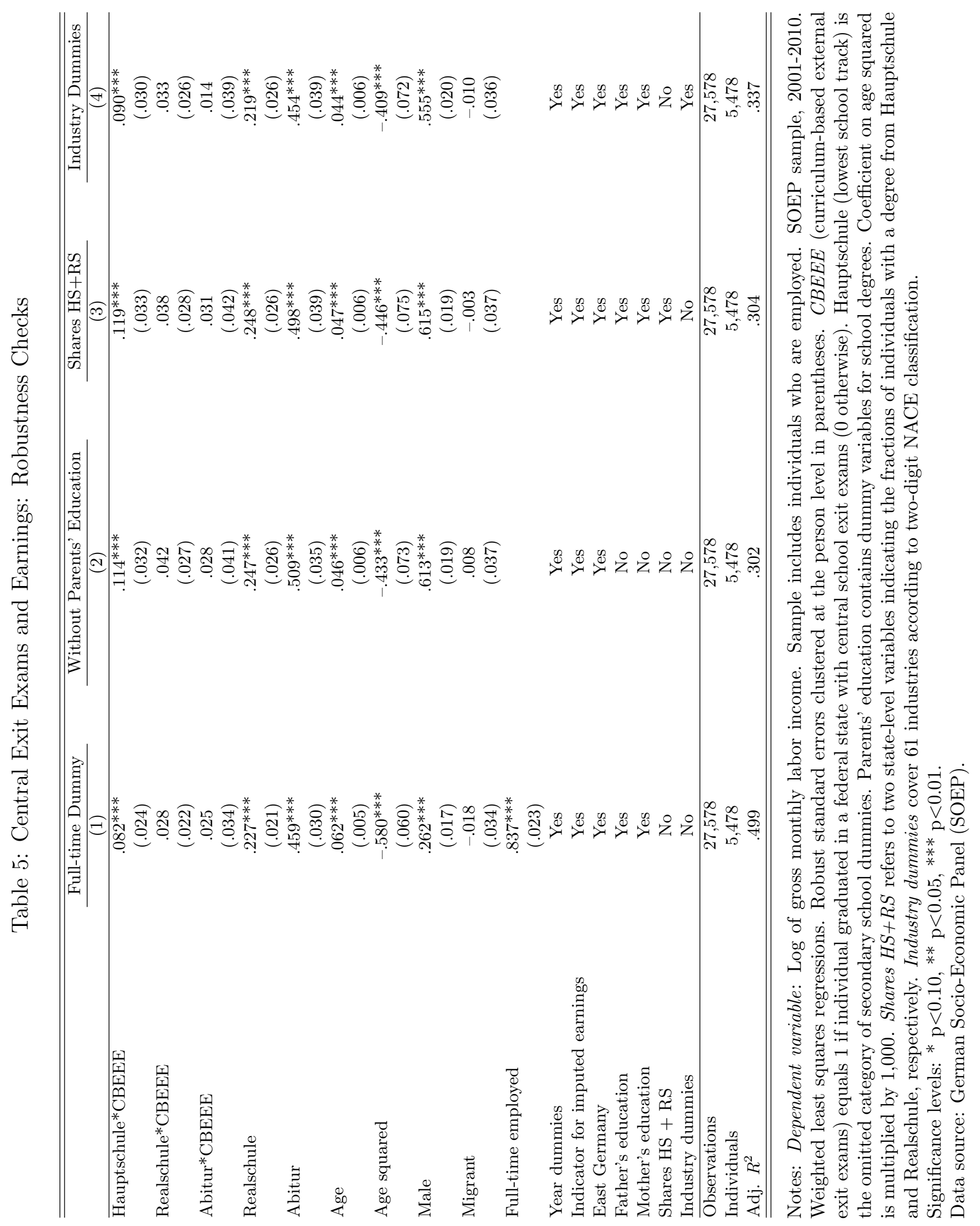


Table 6: Central Exit Exams and Unemployment

\begin{tabular}{|c|c|c|c|}
\hline & \multicolumn{2}{|r|}{ SOEP } & \multirow{3}{*}{$\begin{array}{l}\text { HIS } \\
(3) \\
\end{array}$} \\
\hline & Main Effect & Interactions with School Type & \\
\hline & $(1)$ & (2) & \\
\hline \multirow[t]{2}{*}{ CBEEE } & $-.024^{* * *}$ & & \\
\hline & $(.007)$ & & \\
\hline \multirow[t]{2}{*}{ Hauptschule*CBEEE } & & $-.043^{* * *}$ & \\
\hline & & $(.014)$ & \\
\hline \multirow[t]{2}{*}{ Realschule*CBEEE } & & -.002 & \\
\hline & & $(.009)$ & \\
\hline \multirow[t]{2}{*}{ Abitur*CBEEE } & & $-.032^{* * *}$ & .0001 \\
\hline & & $(.008)$ & $(.005)$ \\
\hline \multirow[t]{2}{*}{ Realschule } & $-.057^{* * *}$ & $-.071^{* * *}$ & \\
\hline & $(.008)$ & $(.010)$ & \\
\hline \multirow[t]{2}{*}{ Abitur } & $-.074^{* * *}$ & $-.077^{* * *}$ & \\
\hline & $(.009)$ & $(.011)$ & \\
\hline \multirow[t]{2}{*}{ Age } & $-.019^{* * *}$ & $-.018^{* * *}$ & $.005^{* * *}$ \\
\hline & $(.003)$ & $(.003)$ & $(.001)$ \\
\hline \multirow[t]{2}{*}{ Age squared } & $.212^{* * *}$ & $.208^{* * *}$ & \\
\hline & $(.029)$ & $(.030)$ & \\
\hline \multirow[t]{2}{*}{ Male } & $-.022^{* * *}$ & $-.023^{* * *}$ & $-.012^{* *}$ \\
\hline & $(.007)$ & $(.007)$ & $(.005)$ \\
\hline \multirow[t]{2}{*}{ Migrant } & $.057 * *$ & $.058^{* *}$ & \\
\hline & $(.024)$ & $(.024)$ & \\
\hline Year dummies & Yes & Yes & No \\
\hline East Germany & Yes & Yes & Yes \\
\hline Father's education & Yes & Yes & Yes \\
\hline Mother's education & Yes & Yes & Yes \\
\hline Observations & 29,339 & 29,339 & 4987 \\
\hline Individuals & 5,727 & 5,727 & 4987 \\
\hline Adj. $R^{2}$ & .040 & .041 & .009 \\
\hline
\end{tabular}

Notes: Dependent variable: unemployed (equals 1 if individual is unemployed and 0 otherwise). Sample includes individuals who are employed or unemployed. SOEP sample refers to 2001-2010; HIS sample refers to 2003. Weighted least squares regressions. Robust standard errors clustered at the person level in parentheses. $C B E E E$ (curriculum-based external exit exams) equals 1 if individual graduated in a federal state with central school exit exams (0 otherwise). Hauptschule (lowest school track) is the omitted category of secondary school dummies. Parents' education contains dummy variables for school degrees. Coefficient on age squared is multiplied by 1,000 .

Significance levels: $* \mathrm{p}<0.10,{ }^{*} \mathrm{p}<0.05,{ }^{* * *} \mathrm{p}<0.01$.

Data source: German Socio-Economic Panel (SOEP) and Graduate Panel of the Higher Education Information System (HIS). 


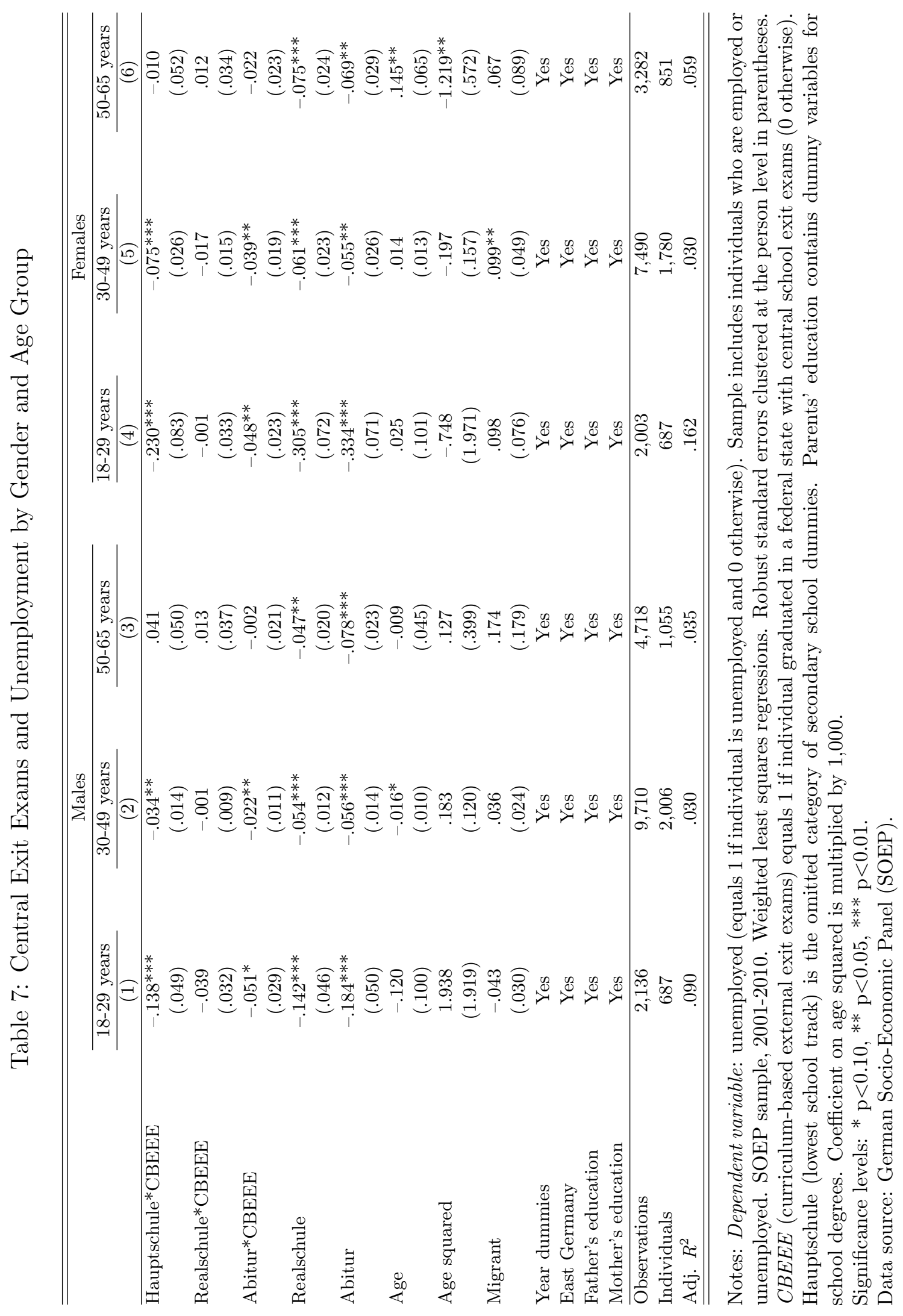


Table 8: Central Exit Exams and Unemployment: Robustness Checks

\begin{tabular}{|c|c|c|}
\hline & $\begin{array}{c}\text { Without Parents' Education } \\
(1)\end{array}$ & $\frac{\text { Shares HS+RS }}{(2)}$ \\
\hline Hauptschule*CBEEE & $\begin{array}{c}-.045^{* * *} \\
(.014)\end{array}$ & $\begin{array}{c}-.046^{* * *} \\
(.014)\end{array}$ \\
\hline Realschule*CBEEE & $\begin{array}{l}-.002 \\
(.009)\end{array}$ & $\begin{array}{l}-.003 \\
(.010)\end{array}$ \\
\hline Abitur*CBEEE & $\begin{array}{c}-.031^{* * *} \\
\quad(.008)\end{array}$ & $\begin{array}{c}-.032^{* * *} \\
(.009)\end{array}$ \\
\hline Realschule & $\begin{array}{c}-.073^{* * *} \\
\quad(.010)\end{array}$ & $\begin{array}{c}-.072^{* * *} \\
(.010)\end{array}$ \\
\hline Abitur & $\begin{array}{c}-.080^{* * *} \\
\quad(.011)\end{array}$ & $\begin{array}{c}-.081^{* * *} \\
\quad(.012)\end{array}$ \\
\hline Age & $\begin{array}{c}-.018^{* * *} \\
(.003)\end{array}$ & $\begin{array}{c}-.018^{* * *} \\
(.003)\end{array}$ \\
\hline Age squared & $\begin{array}{l}.202^{* * *} \\
(.029)\end{array}$ & $\begin{array}{c}.207^{* * *} \\
(.029)\end{array}$ \\
\hline Male & $\begin{array}{c}-.023^{* * *} \\
\quad(.007)\end{array}$ & $\begin{array}{c}-.023^{* * *} \\
(.007)\end{array}$ \\
\hline Migrant & $\begin{array}{l}.052^{* *} \\
(.024)\end{array}$ & $\begin{array}{l}.057^{* *} \\
(.024)\end{array}$ \\
\hline Year dummies & Yes & Yes \\
\hline East Germany & Yes & Yes \\
\hline Father's education & No & Yes \\
\hline Mother's education & No & Yes \\
\hline Shares HS + RS & No & Yes \\
\hline Observations & 29,339 & 29,339 \\
\hline Individuals & 5,727 & 5,727 \\
\hline Adj. $R^{2}$ & .039 & .042 \\
\hline
\end{tabular}

Notes: Dependent variable: unemployed (equals 1 if individual is unemployed and 0 otherwise). Sample includes individuals who are employed or unemployed. SOEP sample, 2001-2010. Weighted least squares regressions. Robust standard errors clustered at the person level in parentheses. CBEEE (curriculumbased external exit exams) equals 1 if individual graduated in a federal state with central school exit exams (0 otherwise). Hauptschule (lowest school track) is the omitted category of secondary school dummies. Parents' education contains dummy variables for school degrees. Coefficient on age squared is multiplied by 1,000. Shares $H S+R S$ refers to two state-level variables indicating the fractions of individuals with a degree from Hauptschule and Realschule, respectively.

Significance levels: * $\mathrm{p}<0.10, * * \mathrm{p}<0.05, * * * \mathrm{p}<0.01$.

Data source: German Socio-Economic Panel (SOEP). 